\title{
RICEFIELDS, A LIMNOLOGICAL PERSPECTIVE
}

\author{
E. Forés and F. A. Comín \\ Department of Ecology, University of Barcelona, Diagonal 645, 08028 Barcelona, Spain
}

Keywords: Ricefields, Microsuccession, Nitrogen, Phosphorus, Landscape, Global ecology.

\begin{abstract}
Ricefields are extremely important ecosystems because they provide food for $40 \%$ of the human populations and extend over a large area (150.106 ha), mostly in SE Asia although rice is cultivated between $50 \mathrm{oN}$ and $40^{\circ} \mathrm{S}$ all around the World. Different aspects of the ecology of flooded ricefields are discussed in order to emphasize some unifying limnological perspectives for ricefields.

Rice paddies are agroecosystems which remain flooded during the growing season (April-September in Europe) and dry during the rest of the year while they are prepared for the next cultivation period. In the ricefields of the Ebro Delta (N.E. Spain), the rice straw buried in the sediment contributes up to 33 and $8 \%$ respectively of the total nitrogen and phosphorus provided by the farmers. Chemical fertilizers are also applied at rates of $110 \mathrm{~kg} \mathrm{~N} \mathrm{ha}^{-1}$ and $20 \mathrm{~kg} \mathrm{P} \mathrm{ha}^{-1}$. The main nutrient outputs are the rice plants ( $70 \%$ and $91 \%$ of total $\mathrm{N}$ and $\mathrm{P}$, respectively), water outflows (15\% and 3\%, respectively) and biogeochemical processes.

Primary production exceeds total respiration in the ricefield water column during the first half of the cultivation period (from flooding until rice tillering, about two months). During this period high oxygen concentrations (7-12 $\left.\mathrm{mg}^{-1}\right)$ and $\mathrm{pH}(8-9.3)$, and low alkalinities (0.9-1.2 meq $\left.\mathrm{I}^{-1}\right)$ are observed. Respiration by living organisms and accumulated organic matter exceeds primary production during the second half of the cultivation period. Low oxygen concentrations (1.7-4.7 $\left.\mathrm{mg} \mathrm{l}^{-1}\right)$ and $\mathrm{pH}(6-7.8)$, and high alkalinities (4-7.3 meq $\left.^{-1}\right)$ are characteristic of this period. These environmental changes are paralleled by a community change in the water column, from a dominance of free living organisms (phytoplankton, small filamentous algae, rotifers, cladocerans) to that of macrophytic vegetation and detritivores.

Ricefields act as ecological filters because outflowing water contains less suspended and dissolved material than inflowing waters. Total nitrogen and phosphorus retention efficiencies for all the cultivation period in the Ebro Delta ricefields were,respectively, 35 and $75 \%$. Physical and biogeochemical processes are responsible for this filtering role of ricefields.

In areas where rice is cultivated extensively a change at landscape scale occurred, from relatively unpredictable natural areas to controlled water flows and increased residence times. Establishment of a gradient of ecosystems at different organizational levels is recommended in order to alleviate impacts on connected aquatic ecosystems. Ricefields are also sites of considerable gass $\left(\mathrm{CO}_{2}\right.$ and $\left.\mathrm{N}_{2} \mathrm{O}\right)$ emission to the atmosphere. Limnological research on ricefields should be enhanced in order to link theoretical aspects (ecosystem functioning) and applied aspects (food production, nature conservation).
\end{abstract}

\section{INTRODUCTION}

Rice cultivation is the most important agricultural activity in the world, by its extension (150.106 ha) and the number of people whose basic food is rice $(40 \%$ of the human population). Most of the rice is cultivated in SE Asia (90\% of the world ricefield area) and in flooded lands (85\% of the total ricefield area) (DE DATTA, 1986).

Limnetica, X: 101-109(1992)

O Asociación Española de Limnología, Madrid. Spain
Temperature requirements for rice growth limits its extension to between $53 \circ \mathrm{N}$ and $40{ }^{\circ} \mathrm{S}$ (SWAMINATHAN, 1984). Rice is mostly cultivated in lands flooded to a depth of $15-25 \mathrm{~cm}$. Rice development takes between 140 and 170 days. In Mediterranean countries the growing season runs from mid spring to early autumn. The characteristics of the soils in alluvial plains formed in the deltas of the large rivers (Nile, Danube, Po, Rhone, Ebro) are excellent for growing a 
plant which, like other emergent macrophytes, occupies three different environments (soil, water, air) at the same time. In some parts of the world rice is also cultivated in deep waters (0.5-3.5 m) (VERGARA, 1985) and in non flooded lands (DE DATTA, 1986).

Rice field area is very low in Europe $(0.3 \%$ of the world rice field area), as is the contribution to world rice production $(0.4 \%)$.

In Spain, where it was introduced with Islamic Culture, is now mainly cultivated in three regions (fig. 1) where a characteristic cultural life has developed around the rice cultivation activities and its particular landscape. From the limnological point of view, rice fields can be considered as temporary aquatic ecosystems where an intense biological activity takes place as result of the development of many different types of biological populations including man.

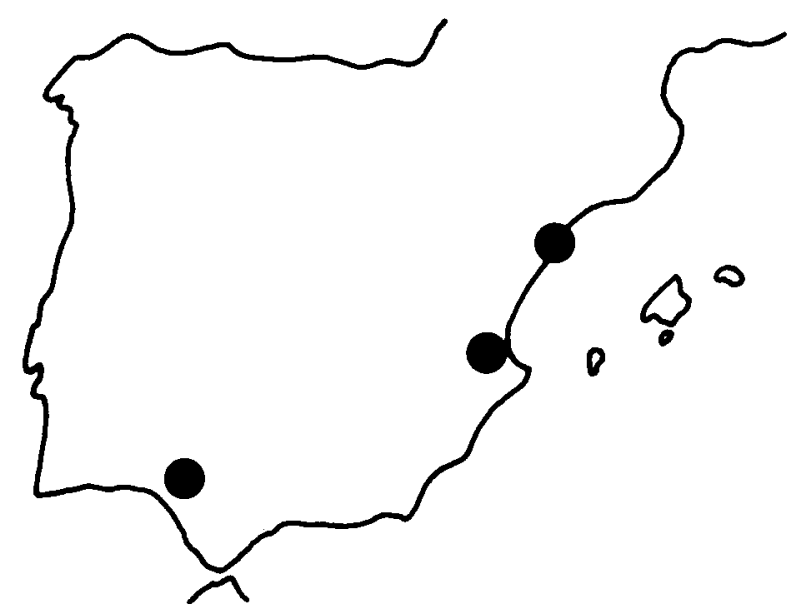

Figure 1. Locition of the three largest Spanish areas where rice is cultivated extensively and natural wetlands are affected by drainage water from the rice fields.

Limnological studies of ricefields in Europe cover the following aspects: faunistic and floristic descriptions (MORONI, 1961, FOX, 1965, BERCZIK, 1972, BOLOS \& MASCLANS, 1975, CHINCHILLA \& COMIN, 1977, FERRER \& COMIN, 1979,, FORES et al., 1987); ecological succession (MUKHAMEDIEV, 1960, ROSSI et al., 1974, PONT, 1977, FERRARI et al., 1984, VAQUER, 1984a, FORES \& COMIN, 1986, MADONI, 1988); biogeochemical processes (GOLTERMAN, 1982, FORES \& COMIN, 1986, ANTONIETTI et al., 1987, MINZONI \& MORONI, 1987, MINZONI et al., 1988, BONETTO et al., 1988, FORES \& COMIN,1989a). Substantial contributions to the limnology of ricefields have been made by researches in other parts of the world (GARCIA, 1973, FERNANDO, 1977, FERNANDO et al., 1980, REDDY et al., 1989, BURESH \& DE DATTA, 1990, FRENEY et al., 1990)

Ricefields have some peculiarities which make them particularly interesting for ecological studies: precise, clear boundaries, both physical and ecological; manageable dimensions at the human scale; great variety of changes in a short period of time; strong interactions between biological and geochemical components.

\section{RICE FIELDS AS AGROECOSYSTEMS}

During the cultivation period, the farmer use biocides and other management techniques to exclude animals (consumers) and competing plants thereby favouring the dominance of rice. Rice is planted as seed $\left(160-225 \mathrm{~kg} \mathrm{ha}^{-1}\right) \mathrm{a}$ week after flooding, but only 5-7\% of the seeds reach the end of the growth period.

The biological cycle of rice compreses a vegetative period (from germination of seeds to ear formation), a reproductive period (from ear to florescence), and a ripening period (from florescence to ripeness), which last about 95 , 20 and 40 days, respectively. The vegetative phase can also be separated in different phases: before, during and after tillering. During tillering, rice develops 4 to 6 stems per plant. Rice biomass grows following a sigmoidal curve reaching $1 / 3$ of the final biomass and a height of $50 \mathrm{~cm}$ by the end of tillering (GREGORY et al., 1979, BARCELO et al., 1980). Ears show the maximum growth rate during the reproductive period. Maximum rice biomass can be observed at the end of the cultivation period, $14,000 \mathrm{~kg} \mathrm{ha}^{-1}$ in the Ebro Delta ricefields. The root system accounts for $22 \%$ and the ears for $41 \%$ of total plant biomass (FORES \& COMIN, 1989).

Large amount of algae and submerged, floating and emergent plants and animals inhabit ricefields along the growing season (PONT \& VAQUER, 1984, COMIN \& FORES, 1989). From October to April most of the Spanish ricefields remain dry. Straw is buried in the sediment, and fields are prepared for the next cultivation period. Some ricefields are waterlogged again after the harvest for hunting and fishing purposes.

Fifty percent of the straw biomass buried in the sediment after the harvest decomposes during the dry period (FORES et al., 1988), releasing nutrients which can later be used by the rice plants. Straw can contribute up to $33 \%$ and $8 \%$ respectively of the total nitrogen and phosphorus provided 
by the farmer (FORES \& COMIN, 1988). In the ricefields in the Ebro Delta $110 \mathrm{~kg} \mathrm{ha}^{-1}$ of nitrogen and $20 \mathrm{~kg} \mathrm{ha}^{-1}$ of phosphorus are also applied as chemical fertilizers by the farmers. These amounts, together the amount provided by the straw, contitute $98 \%$ of the total nitrogen and phosphorus inputs to the ecosystem. Outputs are distributed between rice plants $(70 \% \mathrm{~N}, 91 \% \mathrm{P})$, submerged macrophytes $(1.4 \%$ $\mathrm{N}, 5 \% \mathrm{P})$, water outflows $(15 \% \mathrm{~N}, 3 \% \mathrm{P})$, and biogeochemical processes (FORES \& COMIN, 1989).

Light and nutrients, are as in other ecosystems, the key factors controlling the strong competition between populations occuring in the rice fields. Rice energy productivity (the amount of product obtained per unit of input energy) is quite low in USA ricefields $\left(0.082 \mathrm{~kg} \mathrm{MJ}^{-1}\right)$ compared to other agricultural crops such as corn $\left(0.18 \mathrm{~kg} \mathrm{MJ}^{-1}\right)$ and sorghum (0.11 $\left.\mathrm{kgMJ}^{-1}\right)$ (PIEROTTI et al., 1977). The relationship between any output factor (output energy, yield) and any input factor (input energy, amount of used fertilizer) is asymptotic (fig. 2), as in other agricultural systems (PIMENTEL, 1974). Thus, ricefields are subject to the same general ecological constraints as any other ecosystem. They can be considered agroecosystems in virtue of the fact that humans control their functioning to obtain an agricultural product.

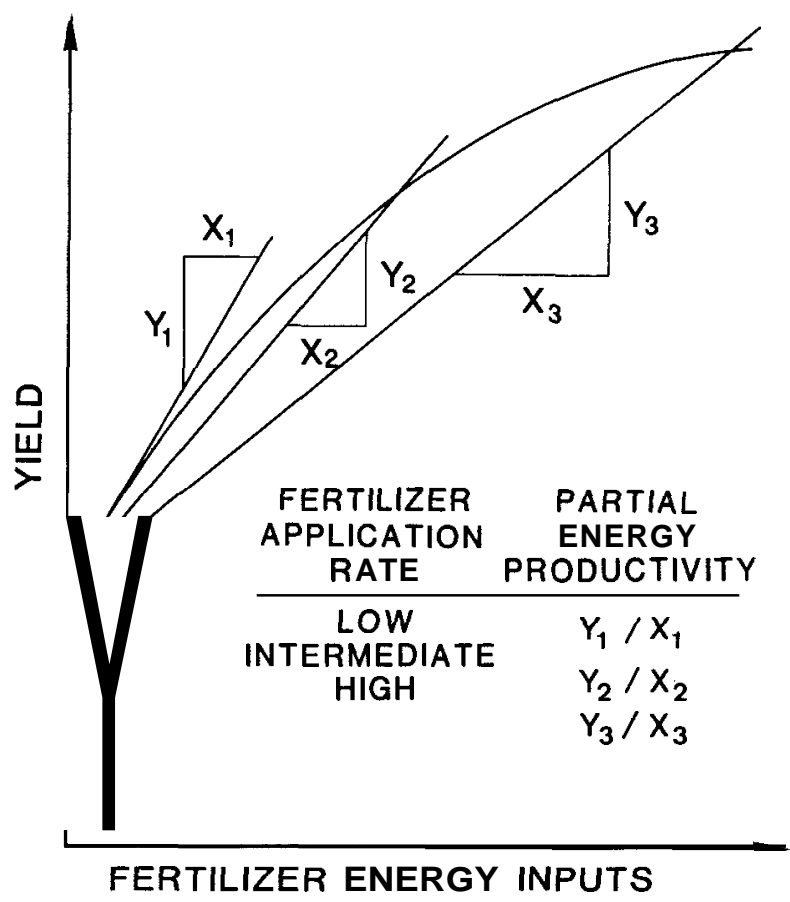

Figure 2. Asymptota relationship between the yield and energy input in agroecosystems showing the decreasing ratio of the effi ciency (yield/energy input) as the inputs increase.

\section{RICEFIELD COMMUNITY STRUCTURE}

Ricefield are highly dynamic ecosystems where physical and chemical characteristics of the water change during the cultivation period. These changes are caused by the increasing complexity of the biological community during the growing season.

In spite of the overwhelming dominance of rice biomass due to human effects, plankton (called heleoplankton in such a shallow water column) and floating and submerged macrophytes are apparent during the first phases of the rice growth, when the light is sufficient to permit photosyntesis in the water column. Phytoplankton develops abundant populations until the tillering phase. We have observed phytoplankton abundances between 5,600 and 19,000 cell $\mathrm{ml}^{-1}$ in the Ebro Delta ricefields (mainly chlorophyceans and diatoms), generally entering the ricefields with the irrigation water. During the first phases of rice growth, the chemical characteristics of the water in the ricefields show clearly a dominance of production over respiration processes: high values of dissolved oxygen (7-12 $\mathrm{mg}^{-\mathrm{l}^{-1}}$ ) and $\mathrm{pH}$ (8-9.3) and low values of alkalinity (0.95-1.2 meq. $\mathrm{l}^{-1}$ (PONT \& VAQUER, 1984: ANTONIETTI et al, 1987; FORES \& COMIN 1987). Rotifera and Cladocera are the dominant components of the heleoplankton (FERRARI et al.,1984; FORES \& COMIN, 1986).

Phytoplankton growth decreases after the tillering phase. During this period, submerged vegetation develops dense populations: filamentous algae (Spyrogyra, Oedogonium, Hydrodyction), rooted macrophytes (Scirpus, Najas, Zannichelia, Potamogeton), and Chara (VAQUER, 1984b, FORES \& COMIN, 1986). Chara is the most abundant genus in the ricefields, and reaches maximum biomasses of $1,000 \mathrm{Kg} \mathrm{ha}^{-1}$ in French ricefields (VAQUER, 1984). During the tillering phase the copepod Acanthocyclops $\mathrm{g}$. vernalis displaces rotifers and cladocerans, forming the most abundant zooplankton population (PONT, 1984, FORES \& COMIN, 1986).

Rice reaches its maximum height and biomass in the reproductive and ripenning periods. Radiation intensities reaching the upper part of the water column are less than $10 \%$ of the incident light at the top of the rice plants (fig. 3) (PONT \& VAQUER, 1984). Submerged vegetation can develop between rice plants, if there is enough light. Ostracoda, with a large number of extraeuropean species (Dole rocypris sinensis, Stenocypris malcolmsoni, Cypris subglobosa,) becomes the most abundant heleoplankton group, with some summer copepoda as Thermocyclops dybowsky or 
Macrocyclops albidus. During these phases, respiration exceeds production in the water columnn according to the low dissolved oxygen concentration (1.7-4.7 $\left.\mathrm{mg.l}^{-1}\right)$ and $\mathrm{pH}$ (67.8) and high alkalinity (4-7.3 meq. l $^{-1}$ (ANTONIETTI et al, 1987; PONT \& VAQUER, 1984; FORES \& COMIN, 1987).

Seasonal changes in the populations of the ricefield water show microsuccession. During the first weeks ofcultivation, ricefields are free of submerged vegetation. Oxygen diffusea freely between air and water, and phytoplankton grows in a clear water column. Cladocera, mainly filtering species, can develop an important population, which feeds on the abundant phytoplankton. Rotifers, a typical r-strategy group, are abundant during this period. During the tillering phase, when rice grows and occupies most of the space in the water column, phytoplankton is displaced hy macrophytic and algal

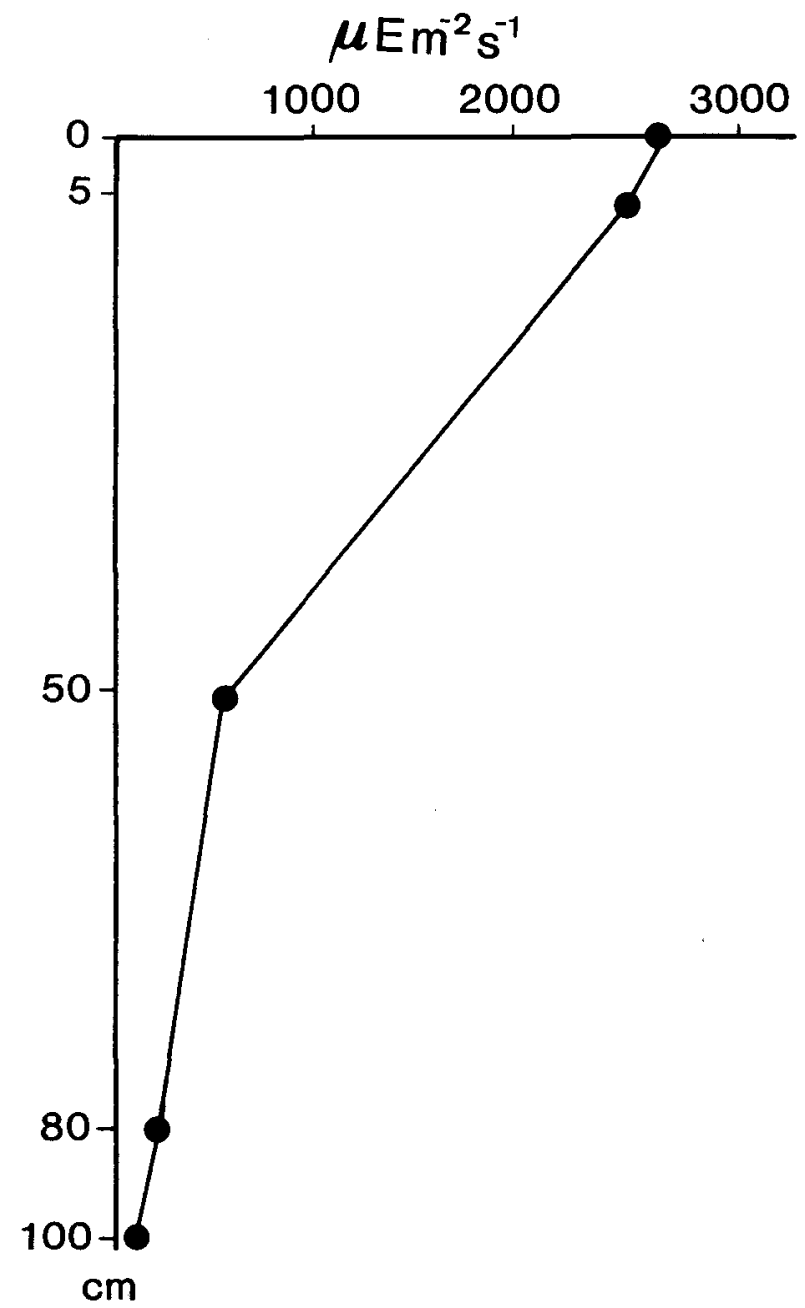

Figure 3. Distribution of the incident light at different heights of the rice plant. vegetation. The fall in the number of phytoplankton cells represents the end of the filtering strategy, and cladocera are replaced by copepoda. This period represents the most important change in the chemical and physical characteristics of the water. Rice cover interferes with oxygen diussion from air to water, and respiration and decomposition processes consume the oxygen in the water. Processes in this phase could be compared to the processes occurring in the hypolimnion of a eutrophic lake. An excess of organic matter consumes oxygen, producing $\mathrm{CO}_{2}$ and lowering the $\mathrm{pH}$. Redissolution of calcium carbonate from the reduced sediment and from the surface of submerged vegetation can take place (GOLTERMAN et al., 1978). The trophic strategy changes over time from filtering to detritivorous and carnivorous nourishment, from organisms relatively close to an $\mathrm{r}$ strategy to organisms relatively close to a k-strategy (PONT, 1977, FORES \& COMIN, 1986). So, spatial heterogeneity, both vertical and horizontal, increases in the ricefields.

A reset microsuccession begins every year after the great disturbance provoked by harvest and ploughing. In spite of the propagules in the sediments (seeds, resting eggs and spores), human activity keeps ricefields at relatively simple organization levels, with a high $\mathrm{P} / \mathrm{B}$ ratio compared to similar natural ecosystems (e.g., wetlands), which is the most general characteristic of systems exploited by humans (MARGALEF, 1984).

\section{RICEFIELDS AS FILTERING SYSTEMS}

Natural systems retaining particulate and dissolved materials (e.g: nutrients) contained in the water which flows through them can be considered as ecological filters (SCHUBEL \& CARTER, 1983). This definition, originally used for marshes and estuaries, can be applied to rice paddies. The ricefields in the Ebro Delta retain particles with increasing efficiency as the crop develops (FORES, 1989), which suggests a physical particle retention mechanism. This mechanism is a function of the increasing complexity of the submerged vegetation and the rice stems. The importance of the latter is evident, since maximum retention occurs toward the end of the crop season.

Chemical and biological processes are also very important in the role of ricefields as filters, as demonstrated by the retention of nutrients, especially the oxidized inorganic forms of dissolved nitrogen and phosphorus.

Nitrogen retention is observed throughout the crop season (fig. 4). It varies between 27 and $88 \%$ of the inputs, depen- 
ding on the period of the growing season considered (FORES, 1989). The proportions of dissolved and particulate forms of nitrogen in the inflowing and outflowing waters are different. In the inflowing water the most abundant form is usually nitrate. The dissolved inorganic form disappears almost completely, and organic and particulate forms become the most abundant. If release of nitrogen is observed it is in the ammonium form.

Phosphorus retention was observed throughout the crop season except during the tillering phase. There are also differences between the proportions of the inorganic, organic and particulate forms in the inflowing and outflowing channels. The most abundant form present in the inflowing water is soluble reactive phosphorus (SRP), which accounts for $66-100 \%$ of the total phosphorus, depending on the period studied. Outflowing water contains less phosphorus than inflowing water (fig. 4). Between 14 and $83 \%$ of the total incoming phosphorus is retained. The most abundant forms in the outflowing water is organic phosphorus during the first growth stages and SRP after the tillering phase. Retention efficiencies for the whole cultivation period of $35 \%$ and $75 \%$ for nitrogen and phosphorus respectively have been calculated for the Ebro Delta ricefields (FORES, 1989) (Efficiency $=(\mathrm{A} / \mathrm{I}) * 100$, where I and A are, respectively, the amounts of nutrient coming into and retained by the systems).

A large loss (28 $\left.\mathrm{kg} \mathrm{ha}^{-1}\right)$ of oxidized forms of nitrogen occurs via denitrification (FORES \& COMIN, 1987). In some Japanese ricefields this process accounts for $38 \%$ of the nitrogen outputs (YAMAGUCHI, 1979). Flooding of the
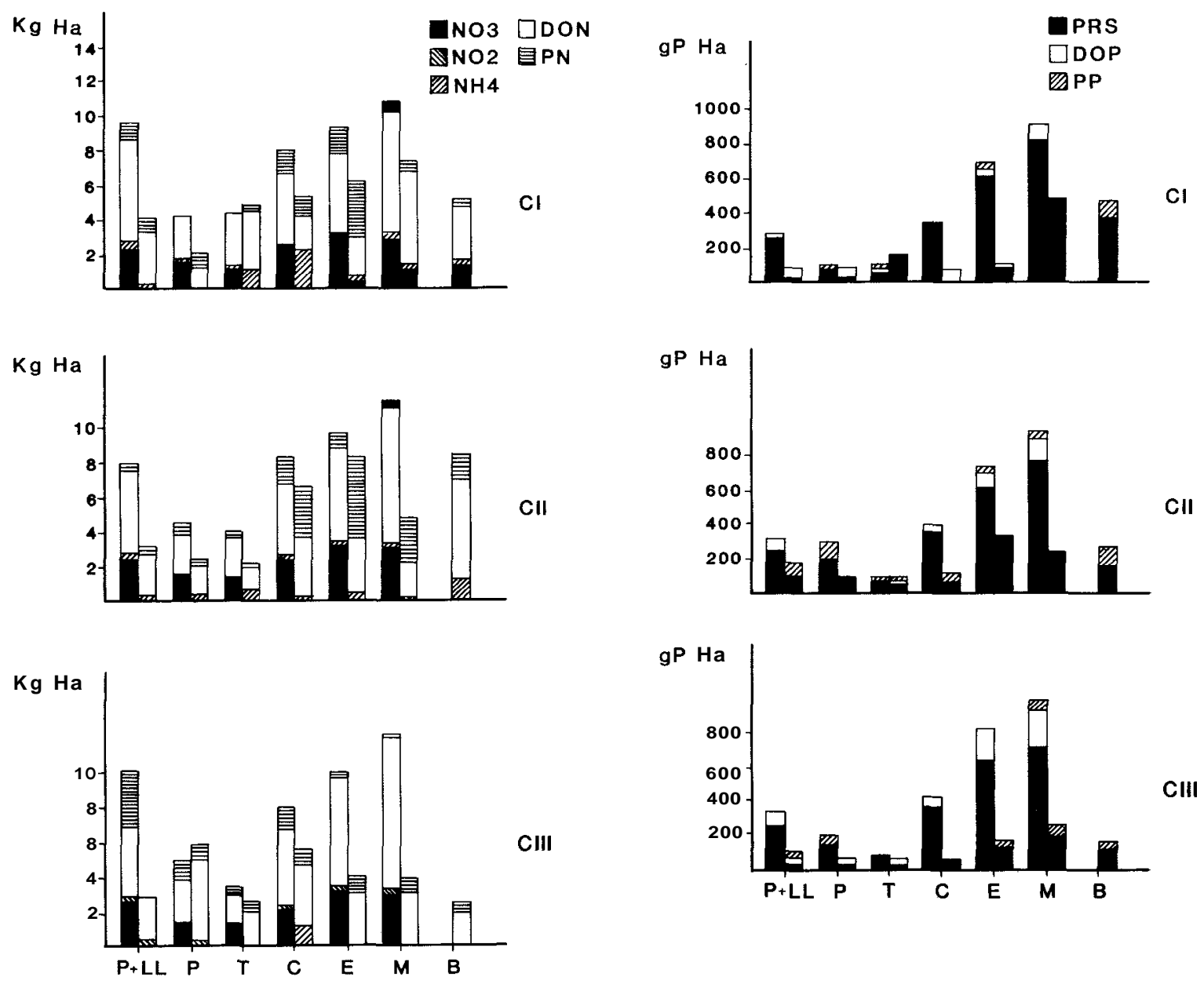

Figure 4. Concentrations of different forms of nitrogen and phosphorus in the inflowing (left bars) and outflowing (righ bars) waters of ricefields in the Ebro Delta, at different stages of the growth of the rice plant ( $\mathrm{P}+\mathrm{LL}$, plant with seed; $\mathrm{P}$, plant without seed; $\mathrm{T}$, tillering; $\mathrm{C}$, height growth; E, flowering; M, ripering; $\mathbf{B}$, last drainage after harvest). 
soil results in the displacement of air spaces by water, and the dissolved oxygen present in the pore water is readily consumed during microbial respiration. Supply of oxygen to the flooded soil occurs by difussion through the overlying water column, and transport through the stems of the rice and other wetland plants to the roots, with subsequent diffusion into the rizhosphere, which can support aerobic microbial populations. The rest of the soil is anaerobic. Microorganisms responsible for denitrification have facultative anaerobic metabolism, but require nitrates, an oxidized form of nitrogen present in aerobic conditions. So, ricefields, with aerobic-anaerobic interphases between sediment and water and the rizosphere, offer adequate conditions for denitrification. The fertilizers used contain ammonium sulphate or urea as nitrogen source. Ammonium present in soil solution is subject to movement in two directions: upward into the oxidized soil layer at the interface soil-water column and downward the plant roots, where it is nitrified by aerobic microorganisms (fig. 5). Nitrates can reach the anaerobic zone where denitrifiers use them. The extent of nitrogen losses through nitrification-denitrification reactions in flooded soils is dependent on the supply of ammonium to the oxidized zones where nitrification potentially occurs. So, slow-release fertilizers can contribute to a decrease in the nitrogen losses due to this process, and increase the oxygen demand in the root zone by increasing the organic content of the soil (REDDY \& PATRICK, 1986).

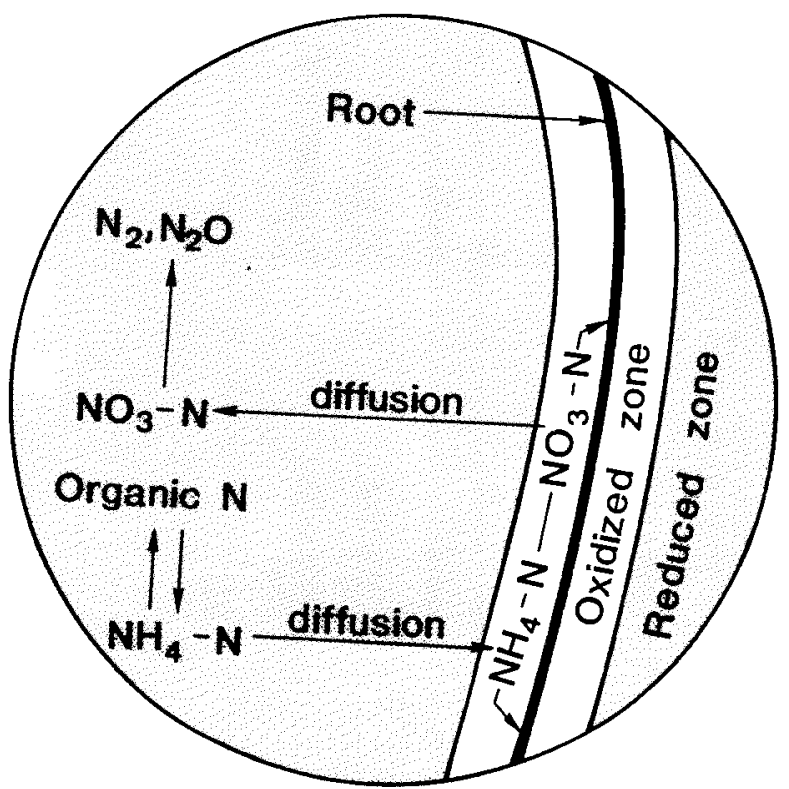

Figure 5. Scheniatic representatum of processes affecting nitrogen transformations in the root zone of rice.
Ammonium from fertilizers, such as ammonium sulphate and urea, can be volatilized as ammonia. The extent of volatilization depends mainly on the ammonium concentration. the $\mathrm{pH}$ and the urease activity of the flooding water; rates as high as $21 \%$ of the nitrogen added were recorded in Italy (PEDRAZZINI \& TARSITANO, 1986). According to the characteristics of the Ebro Delta ricefields, this process could be an important quantitative loss of nitrogen during the first phases of the cultivation period (FORES \& COMIN, 1986).

Inorganic phosphorus precipitation can explain the observed retention of this element by the ricefields (FORES, 1989). Mediterranean ricefield sediment and water have a high calcium concentration (MINZONI, 1986, FORES \& GONZALEZ, 1988). Calcium and phosphorus can combine in different forms to give insoluble compounds that remain in the sediments (GOLTERMAN, 1984). Chemical and physical characteristics of the flood water during the first phases of the rice growth favor phosphorus precipitation, but the presence of an important anaerobic layer under the water-sediment interface may favor phosphorus release to the water. Bacterial metabolism can explain a fraction of this phosphorus release (MINZONI, 1986).

So, ricefields, like many fresh- and salt-marshes, play a role as filters for sediments and nutrients, which accumulate mainly as organic matter in the soil. Rice biomass accumulated during the growing season is similar to those of the most productive emergent macrophytes (e.g., Phragmites communis, Typha latifolia, WETZEL, 1983). The main difference is that nutrient recycling in ricefields is accelerated by man after the harvest. The incorporation of rice straw and fertilizers into the sediments maintains the ricefields at very high levels of productivity if enough water is available. The system is maintained at the same stage year after year with the energy invested by man. In contrast, natural wetlands processes occur more slowly and self-organization of the system produces successional changes in the community structure in the long-term.

\section{RICEFIELDS AT LARGER SCALES}

Although ricefields are ecological filters, their outflows still contain a huge amount of nutrients. They are responsible for accelerated eutrophication of the coastal lagoons in the Ebro Delta. Most of the rice in the world is cultivated in low lands, formerly or potentially wetlands. Land reclamation for extensive rice cultivation is a landscape transformation which involves huge limnological changes. 
Water must be supplied in huge amounts (between $10^{4}$ and $50.10^{4} \mathrm{~m}^{3} \mathrm{ha}^{-1}$ ), usually from rivers, in order to obtain high production. But water is commonly a scarce resource in the regions and during the time rice is cultivated. Competition for water uses among direct human use, agriculture and industry arises in regions such as Catalonia as socioeconomic development proceeds. Moreover, water is not readily available for use. A dense and complex network of irrigation and drainage channels is necessary. These new artificial aquatic ecosystems can be colonized by exotic populations and used for the propagation of species.

Channels also have their own metabolism. In the Ebro Delta drainage channels $25 \%$ of the total nitrogen inputs are lost along the network, while total phosphorus increases in the channel 50\% (FORES, 1989). Nutrient changes in the channels depend on the flow rates and the type and amount of substrate and living organisms (EL HABR \& GOLTERMAN, 1987).

The hydrologic regime of coastal lagoons in the Ebro Delta is controlled by the water drained from the rice field area. The consequences are an inverse seasonal fluctuation of salinity compared to similar Mediterranean coastal lagoons (COMIN et al., 1987, COMIN et al., in press) and intense eutrophication related rates of turnover of fresh and seawater (COMIN et al., 1990).

In the controversy between wetland conservation versus land reclamation for rice cultivation, a gradient of ecosystems at different organization levels (wetlands) is recommended instead of excessive water flow regulation as in the Ebro Delta, to alleviate impacts on connected aquatic ecosystems.

The extremely short water column and high organic matter content of sediments in ricefields favor the export to the atmosphere of gaseous forms of carbon, nitrogen an sulphur originating in the predominantly anoxic conditions of ricefield sediments (PONNAMPERUMA, 1972, SAVANT, \& DE DATTA, 1982). Thus, rice fields, like wetlands in general, are a source of gasses like $\mathrm{CO}_{2}, \mathrm{CH}_{4}$, $\mathrm{NH}, \mathrm{N}_{2}, \mathrm{~N}_{2} \mathrm{O}, \mathrm{SH}_{2}$, which reach the atmosphere across the water column or through the rice plants (SCHUTZ et al.. 1989). Once in the atmosphere, these compounds and, after chemical transformations, their derivatives, contribute to global changes (climatic, acidification).

Some of the processes occur faster in ricefields than in other environments, e.g.: methane production (VALIELA, 1985). However, extrapolation of rates to rice fields in general is risky because of the variety of soils used for rice cultivation (DE DATTA, 1986). One aspect is important because it is quite common: organic matter content is high in ricefield sediments. Furthermore, the amount of chemical fertilizer used is increasing all around the world. These two factors contribute, in general, to enhance microbial activities.

So, limnological reseach of rice fields can contribute to an understanding of ecological processes which operate at different spatial scales. Moreover, linked to agronomic methods, they can contribute to a better production of a basic food, particularly in tropical countries. The link between theoretical and applied aspects of science is complete in the case of ricefield limnology.

\section{ACKNOWLEDGMENTS}

This work was supported by grants from EEC (EV4V132-E) and CICYT ((NAT89-844).

\section{REFERENCES}

ANTONNIETI, R., P. VIAROLI \& F. ANTONIETTI, 1987. Changes in the physical and chemical properties of flooded water and sediment in an experimental ricefield (Reggio Emilia,Italy). Hydi-oh. 144:83-88.

BARCELO,J., G. NICOLAS, B. SABATER \& R. SANCHEZ. 1980. Fisiologia vegetal. Piramide Ed. Madrid. $750 \mathrm{pp}$.

BERCZIK, A., 1972. Periodical changes in aspect of the zoocenoses of Hungarian rice-fields. Verh. Internar. Verein. Limnol. 18:1742-1747.

BOLOS, O. \& F. MASCLANS, 1975. La vegetación de los arrozales en la región mediterránea. Collect. Bot. $4(3): 415-434$.

BONETTO, C., F. MINZONI \& H. L. GOLTERMAN, 1988. The nitrogen cycle in shallow water sediment system of ricefields. 2 Fractionation and bioavailability of organic nitrogen compounds. Hydrohiol. 159:203-210.

BURESH, R. J. \& S. K. De DATTA, 1990. Denitrification losses from puddled rice soils in the tropics. Biol. Fertil. Soils, 9:1-13.

CHINCHILLA, M. \& F.A. COMIN, 1977. Contribució al coneixement dels crustacis del Delta de L'Ebre. Treb. Inst. Car. Hist. Naf. 8:119-144.

COMIN, F.A. \& E. FORES, 1989. Els arrossars. Historia Natural dels Països Catalans 14:340-345.

COMIN, F.A., M. MENENDEZ \& E. FORES, 1987. Salinidad y nutrientes en las lagunas costeras del Delta del Ebro. Limnetica 3:1-8. 
COMIN, F.A., M. MENENDEZ \& J.R. LUCENA, 1990. Proposals for macrophyte restoration in eutrophic coastal lagoons. Hydrobiologia 200/201:427-436.

COMIN, F.A., E. FORES, M. MENENDEZ \& V. ASTORGA, in press. Approach to the characterization of Mediterranean deltaic ecosystems at different scales. In: Ecology of the Po Delta. Italy, Sept. 1990.

De DATTA,S.K. 1986. Producción de arroz.Fundamentos y prácticas. Limusa Ed. Mexico. 690pp.

EL HABR, H. \& H.L. GOLTERMAN, 1987. Input of nutrients and suspended matter into the Golfe du Lion and The Camargue by the River Rhône. Rev. Sci. Eau 6 (4):393-402.

FERNANDO, C. H., 1977. Investigation on the aquatic fauna of tropical ricefields with special reference to South East Asia. Geo-Eco-Trop. 3:169-188.

FERNANDO, C. H., J. L. FURTADO \& R. P. LIM, 1980.

The ecology of ricefield with special refrence to the aquatic fauna. Trop. Ecol. \& Develop. 19:943-951.

FERRARI I., A. de MARCHI, P. MENOZZI, F MINZONI \& F. PICCOLI. 1984. Heleopankton seasonal succession in an experimental ricefield in northern Italy.Verh. Intern. Verein. Limnol. 22:1711-1716.

FERRER, X. \& F.A. COMIN, 1979. Distribució i ecología dels macròfits submergits del Delta de L'Ebre. Butll. Inst. Cat. Hist. Nat. 44(3):111-117.

FORES, E. 1989. Ricefields as filters. Arch. Hydrob. 116 (4): 517-527.

FORES, E. \& F.A. COMIN. 1986. Características limnológicas de los arrozales del Delta del Ebro (N.E. España). Oecol. aquat. 8:39-45.

FORES, E. \& F.A. COMIN. 1987. Chemical characteris tics of the water in the ricefields of the Ebro delta (N.E. Spain). Arch. Hydrob. 111(1): 15-24.

FORES, E. \& F.A. COMIN, 1989a. Balances de nitrógeno y fósforo en arrozales del Delta del Ebro. Bol. R. Soc Esp. Hist. Nat. 84 (3-3):247-257.

FORES, E., M. MENENDEZ \& F.A. COMIN, 1987. Contribución al conocimiento de crustáceos y rotíferos del Delta del Ebro. Misc. Zool. 10:105-111.

FORES, E. \& F.A. COMIN, 1988b. Liberación de C, N y $\mathrm{P}$ durante la descomposición de la paja del arroz. Mediterranea 10:13-18.

FORES,E. \& F.A. COMIN. 1989b. Contenidos de nitrógeno, fósforo y carbono del arroz en diferentes estadios de crecimiento. Rev.Agroq.Tec. Alim. 29(4): 492-500.

FORES,E. \& S. GONZALEZ. 1988. Heterogeneidad espacio-temporal del sedimentode los arrozales del Delta del Ebro. (N.E. España). Oecol. aquat. 9:125-135.
FORES, E., M. MENENDEZ \& F.A. COMIN, 1988. Rice straw decomposition in rice-field soil. Plant and Soil 109:145-146.

FOX, H.M., 1965. Ostracod crustacea from ricefields in Italy. Mem. Ist. Ital. Idrob. 18:205-214.

FRENEY, J. R., A. C. F. TREVITT, S. K. De DATTA, N. OBCEMEA \& J.G. REAL, 1990. The interdependence of ammonia volatilization and denitrification as nitrogen loss processes in flooded rice fields in the Philippines. Biol. Fertil. Soils 9:31-36.

GARCIA,J.L. 1973. Séquence des produits formés au cours de la dénitrification dans les sols des rizières du Senegal. Ann. Microb. 124:351-362.

GOLTERMAN, H. L., 1982. Preliminary observations on nutrient cycles in Scirpus and rice fields in The Camargue. In J.J. Symoens, S.S. Hooper \& P. Compère (eds.). Studies on aquatic vascular plants. Royal Botanical Sopciety of Belgium. Brussels, 200-201.

GOLTERMAN, H. L. 1984. Sediments, modifying and equilibrating factors in the chemistry of freshwater. Verh. Intern. Verein Limnol. 22:23-59.

GOLTERMAN H.L., R.S. CLYMO \& M.A.M. OHNSTAD. 1978. Method for physical and chemical analysis of freshwaters. IBP Handbook 8. Blakwell Ed. Oxford. Edinbourgh. 214pp.

GREGORY, P.J., D.V. CRANFORD \& M. McGOWAN. 1972. Nutrient relations of winter wheat.1. Accumulation and distribution of Na, K, Ca, Mg, P, S and N. J.Agric. Sci. Camb. 93:485-494.

MADONI, P., 1988. Distribution and seasonal succession of ciliated Protozoa in a ricefield ecosystem: A three-year study. Verh. Internat. Verein. Limnol. 23:1063-1067.

MARGALEF, R., 1984. Ecología. Ed. Omega, Barcelona, 951 págs.

MINZONI,F. 1986. Studio di processi legati ai cicli dell'azoto e del fosforo nell' ecosistema risaia. Tesi dottorato di ricerca. Parma.Italia.145pp.

MINZONI, F. \& A. MORONI, 1987. Phosphorus balance of an experimental ricefield in the Po plain (Italy). Agric. Ecosis. \& Evironm. 18:223-230.

MINZONI, F., C. BONETTO \& H.L. GOLTERMAN, 1988. The nitrogen cycle in shallow water sediment system of ricefields. 1 The denitrification process. Hydrobiol. 159:189-202.

MORONI, A., 1961. L'ecosistema de risaia. Ann. Fac. Agraria dell'U.C.S.C., 3:489-625.

MUKHAMEDIEV, A.M., 1960. Contribution to the hydrobiology of the ricefields of the Fergana Valley. Sci. Notes. Uzbek State Pedagogical Inst. Fergana (Biol.) 6:1-82. 
PEDRAZZINI, F.R. \& R. TARSITAN0.1986. Ammonia volatilization from flooded soil following urea application. Plant \& Soil 91:101-107.

PIEROTTI, A., A.G. KELLER \& A.J. FRITSCH, 1977. Energy and food. CSPI Energy Series X. Centre for Sciences in the Public Interest. Washington D.C.

PONNANPERUMA, F.N., 1972. The chemistry of submerged soils. Adv. Agron. 24:29-96.

PONT,D. 1977. Structure et évolution saissonikre des populations de copépodes, cladocères et ostracodes des rizières de Camargue.Ann.Limnol. 13(1): 15-28.

PONT,D. 1984. Recherches quantitatives sur l'héléoplancton des rizières de Camargue. Thèse Doct. Sci. Nat. Provknce (Marseille) 300 pp.

PONT,D. \& A. VAQUER. 1984. Quelques caractéristiques physico-chimiques de l'eau de submersion des rizikres de camargue (France): rôle de la végétation inmergée et émergée. Ecol. Medit. 10(1-2): 133-145.

REDDY, K.R. \& W.H.Jr. PATRICK. 1986. Denitrification losses in flooded ricefields.In: Nitrogen Economy of flooded rice soils. 99-116. S.DE DATTA \& W.H. PATRICK Jr. Ed. Dordrecht. 186pp.

REDDY, K. R., W. H. PATRICK Jr. \& C. W. LINDAU, 1989. Nitrification-denitrification at the plant root-sediment interface in wetlands. Limnol. Oceanogr. 34(6): 1004-1013.

ROSSI, O., A. MORONI, P. BARONI \& P. CARAVELLO, 1974. Annual evolution of the zooplankton diversity in twelve italian ricefields. Boll. Zool. 41,3.

SAVANT, N.K. \& S.K. DE DATTA, 1982. Nitrogen transformations in wetland rice soils. Adv. Agron. 35:241-302.

SCHUBEL,R. \& V.S. KENNEDY. 1983. The estuary as a filter: an introduction. In: The estuary as a filter 1-15. KENNEDY Ed. Academic Press. Orlando. Florida.
SCHUBEL,R. \& H.H. CARTER. 1983. The estuary as a filter for fine-grained suspended sediment. In: The estuary as a filter. 81-105. KENNEDY Ed. Academic Press. Orlando. Florida.

SCHUTZ, H., W. SEILER \& R. CONRAD, 1989. Processes involved in formation and emission of methane in rice paddies. Biogeochem. 7:33-53.

SEILER, W., A. HOLZAPEL-PSCHORN \& C. R. SCHARITE, 1984. Methane emmission from rice paddies. J. Atoms. Chem. 1:241-268.

SINGH, V.P., T.H. WICKHAM \& I.T. CORPUZ. 1978. Nitrogen movement to Laguna Lake through drainage from ricefields. Internat. Conference on water Pollution Countries. Bangkok. Thailand.

SWAMINATHAN, M.S. 1984. Arroz. Invest.Ciencia. 90:52-62.

VALIELA, I., 1985. Marine Ecological Processes. Springer-Verlag, N.Y., 543 pp.

VAQUER, A., 1984a. La production algale dans les rizières de Camargue pendant le pkriode de submersion. Verh. Intern. Ver. Limnol. 22:1615-1654.

VAQUER, A. 1984b. Biomasse et production des characees dans les rizikres de Camargue (France) et leur importance écologique. Oecol. Plant. 5(19):299-313.

VERGARA, B.S., 1985. Growth and development of the deep water rice plant. IRRI Res. Pap. Ser. 103. International Rice Research Institute, Los Baños. Laguna. Philippines, 38 PP.

WETZEL, R.G., 1983. Limnology. Saunders College Publ., Philadelphia, 767 págs.

YAMAGUCHI,T. 1983. Biological nitrogen fixation in flooded ricefield.In:Nitrogen and Rice 193-206.IRRI.Brady Ed. Philippines. 499pp. 